\title{
Performance of wheat varieties grown from seeds with different vigor levels ${ }^{1}$
}

\author{
Felipe Koch ${ }^{2}$, Manoela Andrade Monteiro ${ }^{2}$ Emanuela Garbin Martinazzo ${ }^{3}$, Jessica Mengue Rolim ${ }^{2 *} \mathbb{D}$, \\ Tiago Pedón, Tiago Zanatta Aumonde ${ }^{2}$ \\ 10.1590/0034-737X202269010014
}

\begin{abstract}
The objective of this study was to evaluate the performance of wheat plant grown from seeds with different vigor levels. The experimental design was randomized blocks in a $3 \times 3$ factorial design (cultivar $\mathrm{x}$ vigor level) with four replications. The wheat cultivars were Tbio Toruk, Tbio Mestre and Tbio Iguaçu. The classification of vigor levels was high, medium and low, determined by several vigor procedures. The following evaluations were performed: plant height, number of spikelets in the main tiller, number of seeds in the main tiller, seed mass in the main tiller, number of fertile tillers, number of seeds in tillers, seed mass in tillers, number of plants. $\mathrm{m}^{-2}$, number of spikes. $\mathrm{m}^{-2}$, and grain yield per hectare. The use of high vigor seeds provides a greater number of wheat plants and spikes per area. Grain yield is affected significantly by seed vigor level: there is an increase of up to $11 \%$ by using high vigor seeds compared to low vigor seeds.
\end{abstract}

Keywords: Triticum aestivum L; high vigor; grain yield.

\section{INTRODUCTION}

Wheat (Triticum aestivum L.) is one of the most relevant crops in the world, considered among winter cereals as one of the species that has the greatest economic relevance (Takeiti, 2015).

In Brazil, production is concentrated in the Southern region, which is responsible for more than $90 \%$ in the country total wheat production. However, the Brazilian wheat production accounts for about $50 \%$ of the national demand. Thus, Brazil is a major importer of wheat. One of the factors that cause this situation is low crop productivity (Conab, 2019).

In this context, the country has an interest in increasing the production of wheat, because in addition to the demand for grains, the cultivation of the cereal contributes to the supply of mulch for the production of summer crops such as soybeans and corn (Conab, 2017). Therefore, in order to explore the potential for wheat and to meet domestic demand in Brazil, adequate crop management strategies, promising genotypes and high quality seeds are needed (Abati et al., 2017). In this sense, seed quality is defined by the sum of its genetic, physical, physiological, and sanitary attributes (Peske et al., 2019). Among the attributes of physiological quality, vigor is highlighted as extremely important as it is directly related to germination, emergence and seedling growth rates in the field, also influencing the yield of several crops (Rossi et al., 2017).

Several studies have pointed out the effect of seed vigor on crop growth and grain yield. Carneiro et al. (2020), evaluating different levels of seed vigor in soybean populations, observed that the population from seeds of high vigor presented grain yield $30 \%$ higher than the population formed by low vigor seeds. Egli \& Rucker (2012) confirmed that corn seeds with high vigor always have a seedling emergence considered more uniform than those with low vigor. As for wheat, Pimentel et al. (2018) found that seeds with high vigor tolerated greater sowing depths,

Submitted on August 19th, 2020 and accepted on June 10 $0^{\text {th }}, 2021$.

1 This work is part of the first author's doctoral thesis.

${ }^{2}$ Universidade Federal de Pelotas, Programa de Pós-Graduação em Ciência e Tecnologia de Sementes, Faculdade de Agronomia Eliseu Maciel, Departamento de Fitotecnia, Pelotas, Rio Grande do Sul, Brazil. felipe.koch@hotmail.com; manu_agro@hotmail.com; eng.jessicarolim@gmail.com; tiago.pedo@gmail.com; tiago.aumonde@gmail.com

${ }^{3}$ Universidade Federal do Rio Grande, ICB, Instituto de Ciências Biológicas, Rio Grande, Rio Grande do Sul, Brasil. emartinazzo@gmail.com

*Corresponding author: eng.jessicarolim@gmail.com 
presenting a higher percentage of emergence and consequently a greater number of plants per area, which should be considered during the implantation and management of crop production. In this context, Abati et al. (2018) concluded that highly vigorous seeds favor the establishment of the stand and development of plants in the initial phenological stages and the productivity of wheat grains.

However, even though these effects of seed vigor on wheat development has been studied, it may vary according to cultivar, environment and production management.

Thus, the objective of the study was to evaluate the performance of different wheat cultivars grown from seeds with different vigor levels.

\section{MATERIALS AND METHODS}

For data collection, experiments were carried out under different field conditions at two growing sites. The cultivation Site 1 was the experimental area of the Eliseu Maciel Agronomy Faculty, Federal University of

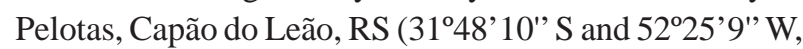
altitude of 67 meters). The cultivation Site 2 was an area belonging to the municipality of Nova Boa Vista, RS (27 $58^{\prime} 45^{\prime \prime} \mathrm{S}$ and 53'0'54' $\mathrm{W}$, altitude of 421 meters). The area in Capão do Leão, RS, has a soil classified as Albaqualf (USDA, 1999). The soil physical and chemical characteristics at the $0-20 \mathrm{~cm}$ layer are $\mathrm{pH}\left(\mathrm{H}_{2} \mathrm{O}\right): 5.3, \mathrm{P}$ and $\mathrm{K}$ : 55.7 and $88 \mathrm{mg} . \mathrm{dm}^{-3}$, respectively; $\mathrm{Ca}, \mathrm{Mg}, \mathrm{Al}$,

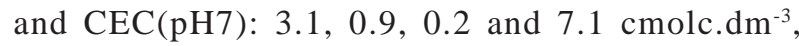
respectively; and base saturation, organic matter and clay: 61, 1.93 and 16\%, respectively. The area in Nova Boa Vista (Site 2) has a soil classified as Alfisol (USDA, 1999). Its physical and chemical characteristics at the 0$20 \mathrm{~cm}$ layer are $\mathrm{pH}\left(\mathrm{H}_{2} \mathrm{O}\right): 5.5, \mathrm{P}$ and $\mathrm{K}: 8$ and $115 \mathrm{mg} . \mathrm{dm}$ ${ }^{3}$, respectively; $\mathrm{Ca}, \mathrm{Mg}, \mathrm{Al}$, and $\mathrm{CEC}(\mathrm{pH} 7): 7.9,3.4,0.1$ and $16.5 \mathrm{cmolc} . \mathrm{dm}^{-3}$, respectively; and base saturation, organic matter and clay: 70, 3.73 and $62 \%$, respectively.

The climate of both cultivation sites is Cfa, with welldistributed rains and hot summers. Meteorological data on maximum and minimum temperatures, solar radiation and rainfall, during the period of conduction of the experiments, are presented in Figure 1.

For Site 1, the climatological data were obtained from the Pelotas-RS Agroclimatic Station. For Site 2, data were collected from the meteorological station of Palmeira das Missões, RS.

The experimental design was randomized blocks in a $3 \times 3$ factorial design (cultivar $x$ seed vigor level) with four replications. The treatments consisted of a combination of three wheat cultivars (Tbio Toruk, Tbio Mestre and Tbio Iguaçu) and three vigor levels (high, medium and low).
The experimental plots consisted of five lines two meters long with an interrow spacing of 0.17 meters. The seed density was 394 seeds. $\mathrm{m}^{-2}$ with $10 \%$ correction aiming to reach a stand with 350 plants. $\mathrm{m}^{-2}$. The three central lines of each plot were considered as the useful area; 0.25 $\mathrm{m}$ from each end was excluded, resulting in a useful area of $1,275 \mathrm{~m}^{2}$.

The ranking of wheat seed vigor levels was determined laboratory the Graduate Program in Seed Science and Technology of the Federal University of Pelotas. For this purpose, the modified accelerated aging method was used. It consists in the packing of seeds on a metallic screen fixed inside plastic boxes ("gerbox") containing $40 \mathrm{~mL}$ of saturated saline solution each (Pedroso et al., 2010).

From the initial seed lots with high vigor seeds of each cultivar, the modified accelerated aging periods were determined to obtain medium and low vigor lots using pre-tests. The aging periods were 96 and 108 hours for the cultivars Tbio Toruk and Tbio Mestre, and 84 and 96 hours for the cultivar Tbio Iguaçu. The high vigor seed lot of each cultivar was not submitted to accelerated aging.

The seed quality was evaluated after ranking the vigor levels aiming to maintain lots with a statistically equal germination, however with different vigor levels. For this, a germination test was performed using four samples with four subsamples of 50 seeds per treatment. The seeds were arranged to germinate in rolls composed of three sheets of germination paper moistened with 2.5 times the mass of the dry substrate. The rolls were kept in a BOD germination chamber at $20{ }^{\circ} \mathrm{C}$ and a photoperiod of 12 hours. The evaluation of the percentage of normal seedlings was performed eight days after sowing (Brasil, 2009).

In addition to germination, the vigor was evaluated by the seedling emergence in the field test using four samples of 100 seeds per treatment. The sowing was performed in the soil at a spacing of $0.17 \mathrm{~m}$ between lines, and at a sowing depth of $3 \mathrm{~cm}$. The evaluation was performed 21 days after sowing, and the results were expressed as percentage of normal emerged seedlings.

For the evaluation of the performance of plants population in relation to productivity attributes, a manual sowing of different cultivars was carried out aiming a uniform distribution of seeds, in the two cultivation sites (Capão do Leão - Site 1 and Nova Boa Vista -Site 2).

In both crop sites, the no-tillage system was used. The fertilization was performed according to previous chemical analysis and followed the recommendations of the Handbook of Fertilization and Liming of the States of Rio Grande do Sul and Santa Catarina (CQFS, 2004). The fertilization consisted of $280 \mathrm{~kg} \cdot \mathrm{ha}^{-1}$ of N-P-K (10-20-20) and two applications of 135 and $100 \mathrm{~kg} \cdot \mathrm{ha}^{-1}$ of urea $(45 \%$ 
$\mathrm{N}$ ), which were carried out at the tillering and elongation stages. Pest and disease controls were carried out in a preventive manner as recommended for the crop (Embrapa, 2017).

Harvesting was performed when seeds reached approximately $18 \%$ moisture. After harvesting, seeds were dried in a stationary dryer at an air temperature of $40{ }^{\circ} \mathrm{C}$ and a relative humidity in between 40 and $70 \%$ (Peske et al., 2019) until reaching $12 \%$ humidity.

For the evaluation of the productivity components, ten plants of each treatment were randomly sampled per plot. The following evaluations were performed: plant height (PHe), number of spikelets in the main tiller (Nspmt), number of seeds in the main tiller (Nsmt), seed mass in the main tiller (Smmt), number of fertile tillers (Nft), number of
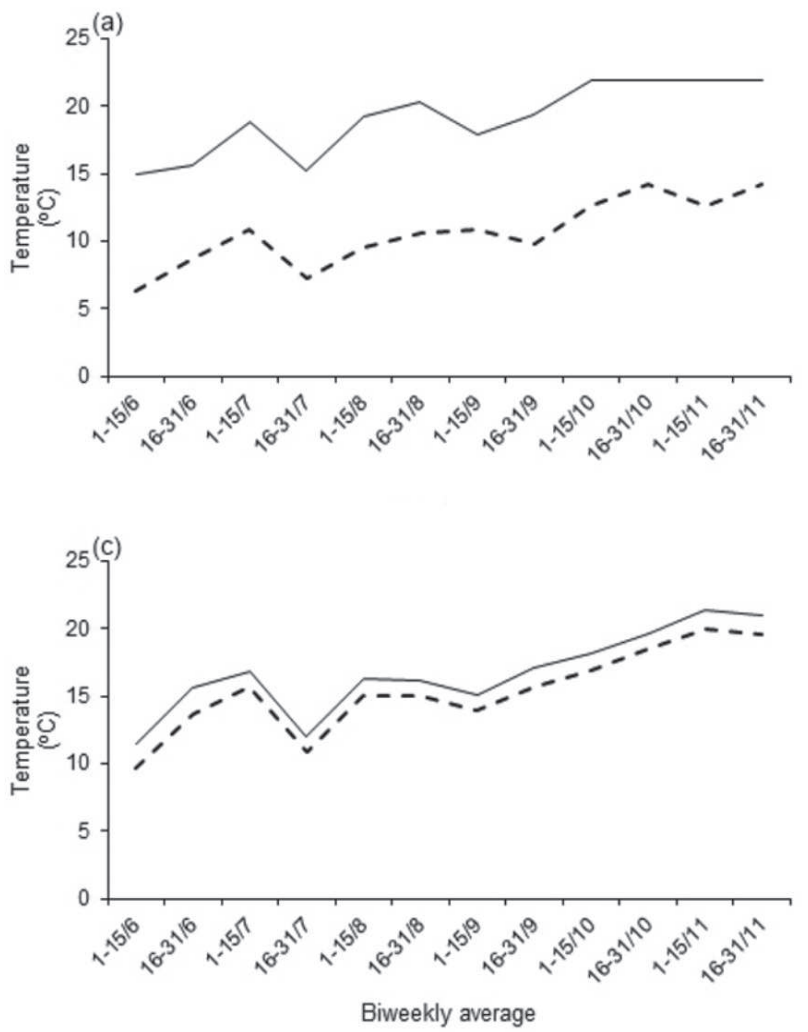

seeds in the tillers (Nst), seed mass in the tillers (Smt), number of plants. $\mathrm{m}^{-2}$ (Npla), number of spikes.m-2 (Nsp), and grain yield per hectare in $\mathrm{kg} \cdot \mathrm{ha}^{-2}$ (Prod).

Data were submitted to analysis of variance by $\mathrm{F}$ test at $5 \%$ probability and, if significant, the means were compared by Duncan test at $5 \%$ probability.

\section{RESULTS AND DISCUSSION}

The characterization of seed lots of the three cultivars after accelerated aging can be observed in Table 1 . Accelerated aging differentiated lots into three vigor levels (high - 80-85\%, medium - 71-77\%, low - 60-63\%), corroborating the results of seedling emergence in the field. However, it kept germination rates without statistical differences, regardless of the evaluated cultivar.
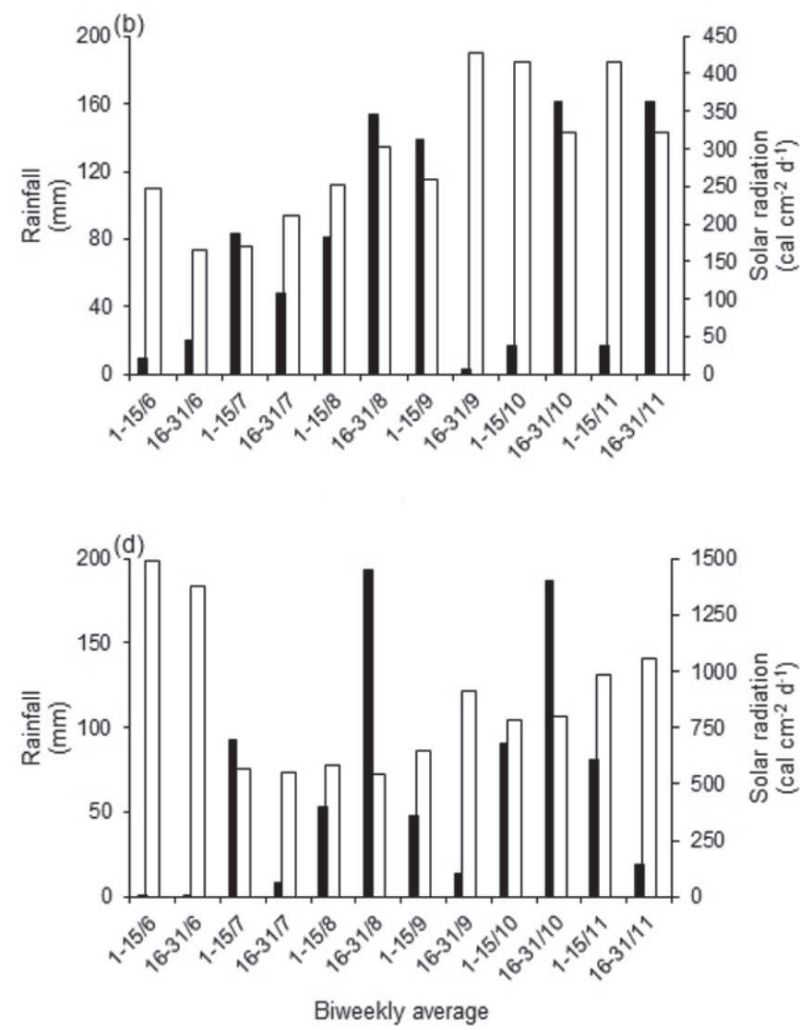

Figure 1: Maximum temperature, minimum temperature, rainfall and solar radiation at Capão do Leão, RS (a, b), and Nova Boa Vista, RS (c, d), during the development of wheat plants.

Table 1: Initial characterization of seed lots of wheat (T. aestivum L.) used in the evaluation of the performance of plants in the field, Capão do Leão, RS

\begin{tabular}{|c|c|c|c|c|c|c|c|c|c|}
\hline \multirow{2}{*}{$\begin{array}{l}\text { Vigor } \\
\text { Level }\end{array}$} & \multicolumn{3}{|c|}{$\begin{array}{c}\text { Germination after } \\
\text { accelerated aging }(\%)\end{array}$} & \multicolumn{3}{|c|}{$\begin{array}{c}\text { Germination } \\
(\%)\end{array}$} & \multicolumn{3}{|c|}{$\begin{array}{l}\text { Seedling emergence } \\
\text { in the field }(\%)\end{array}$} \\
\hline & Toruk & Mestre & Iguaçú & Toruk & Mestre & Iguaçú & Toruk & Mestre & Iguaçú \\
\hline High & $85 a^{*}$ & $83 \mathrm{a}$ & $80 \mathrm{a}$ & $93 \mathrm{a}$ & $92 \mathrm{a}$ & $88 \mathrm{a}$ & $67 \mathrm{a}$ & $62 \mathrm{a}$ & $60 \mathrm{a}$ \\
\hline Medium & $77 \mathrm{~b}$ & $75 \mathrm{~b}$ & $71 \mathrm{~b}$ & $90 \mathrm{a}$ & $90 \mathrm{a}$ & $87 \mathrm{a}$ & $54 \mathrm{~b}$ & $51 \mathrm{~b}$ & $48 \mathrm{~b}$ \\
\hline Low & $60 c$ & $63 c$ & $61 \mathrm{c}$ & $88 \mathrm{a}$ & $90 \mathrm{a}$ & $88 \mathrm{a}$ & $41 \mathrm{c}$ & $41 \mathrm{c}$ & $40 \mathrm{c}$ \\
\hline$\overline{\mathrm{CV}(\%)}$ & & 4,02 & & & 3,05 & & & 8,82 & \\
\hline
\end{tabular}

*Means followed by the same lowercase letter in column do not differ by Tukey test $(\mathrm{p}<0.05)$. 
By evaluating the performance of plants grown from seeds with different levels of vigor, it was verified for the study carried out in Capão do Leão (Site 1) that only plant height showed a significant interaction between cultivar factors and vigor levels (Table 2). For the study carried out in Nova Boa Vista (Site 2), the number of plants. $\mathrm{m}^{-2}$ showed a significant interaction between cultivars and vigor levels. There were no significant differences at the cultivar Site 1 as for the number of plants. $\mathrm{m}^{-2}$ among cultivars (Table 2).

The use of high vigor seeds allowed obtaining the highest number of plants per unit area. Even if the germination was the same among seeds of the three lots, the greater vigor allows a superior establishment of plants in the field. After sowing, there was a period of absence of rainfalls of 11 and 25 days, respectively, at cultivation Sites 1 and 2 (Figure 1). The lack of rainfalls reduced soil moisture. This possibly affected seedling emergence, with a more pronounced effect on treatments with low vigor seeds (Table 2).

According to França-Neto et al. (2016), the use of high vigor seed lots is highly recommended, aiming to ensure an adequate population of plants even when under stress conditions, which ensures crop productivity.

It can be seen in table 3 that the plant height was higher for Tbio Iguaçú for all vigor levels. For the Tbio Toruk cultivar, the lowest values were observed for this variable (Table 3). No significant differences were observed in plant height between seed vigor levels for the Tbio Toruk cultivar. For the cultivar Tbio Mestre, plant height values were higher when grown from low vigor seeds. However, values did not differ from plants grown from high vigor seeds. For the cultivar Tbio Iguaçú, plant height values were higher for plants grown from high and medium vigor seeds.

Due to the differences between the wheat cultivars and the edaphoclimatic conditions of the southern region of Brazil, it is essential to evaluate the different genotypes, and their interaction with the environment, since the success of a cultivar depends directly on its performance in the cultivation area (Scheeren et al., 2011).

Thus, the cultivars have several inherent characteristics of development and are responsive according to the conditions of cultivation. In this sense, the cultivar Tbio Toruk has as one of its characteristics the short stature, while the cultivars Tbio Mestre and Tbio Iguaçu have plant stature considered medium to low and medium to high, respectively, which may explain the different results obtained referring to the height of plants, when comparing the three cultivars.

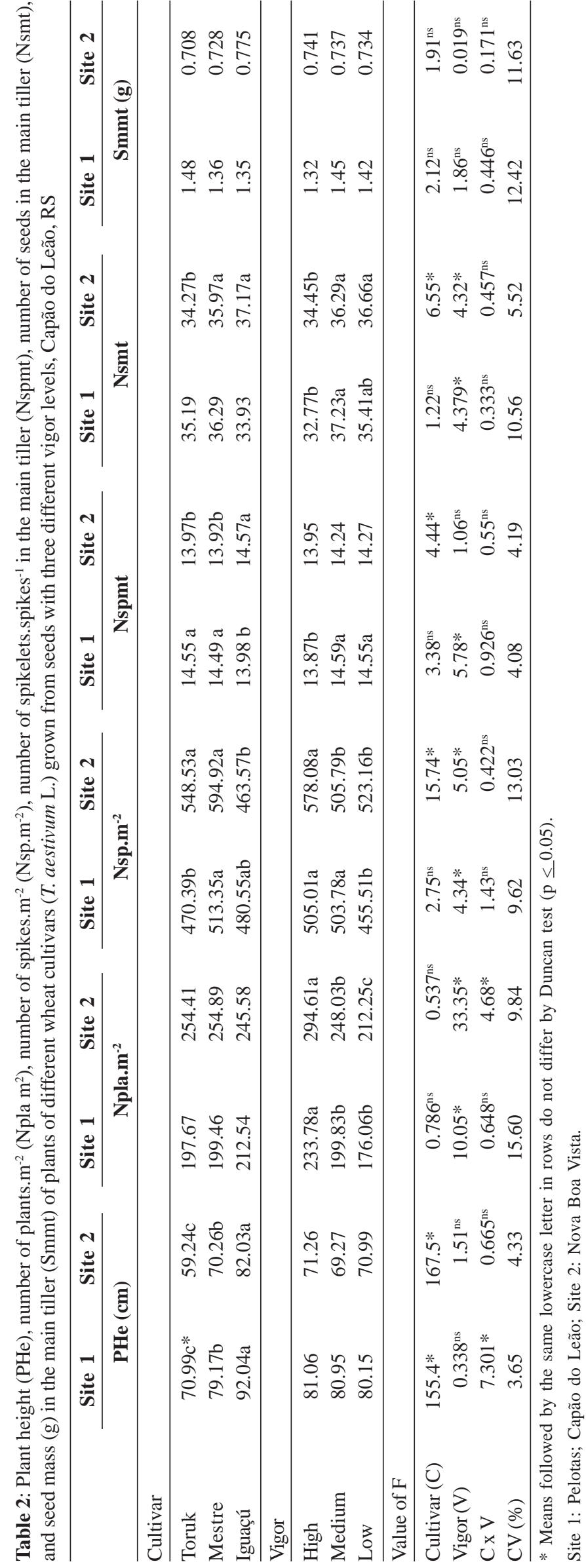

Rev. Ceres, Viçosa, v. 69, n.1, p. 113-120, jan/feb, 2022 
As for the number of plants. $\mathrm{m}^{-2}$, only for high vigor seeds, the cultivars showed a significant difference between themselves, in which Tbio toruk presented the highest values, differing from Tbio Mestre and Tbio Iguaçu which did not differ between them. Furthermore, for all cultivars treatments consisting of high vigor seeds obtained a greater number of plants. $\mathrm{m}^{-2}$. However, for the cultivars Tbio Mestre and Tbio Iguaçú, there were no significant differences between high and medium vigor seeds.

The use of low vigor seeds may lead to a decrease in emergence speed, uniformity, total seedling emergence, initial size, dry matter production and plant growth rates, which can affect the establishment of adequate stands (Kolchinski et al., 2005). Thus, the influence of seed vigor on the emergence of seedlings in the field, in the establishment of the population and in the initial development of plants is a consensus in the scientific environment and also in the productive sector (Marcos Filho, 2015; Ebone et al., 2020). According to Abati et al. (2017) seeds with high vigor have greater ability to use the resources of the environment, resulting in plants that establish themselves in the field in less time, occupy the cultivation environment better and have greater potential for growth and productivity, which can be associated in this case to the results obtained.

Other studies also corroborate the data obtained, in which plants from seeds of high vigor showed better performance. Rossi et al. (2017) found influence of the vigor of soybean seeds in the emergence of seedlings in the field, with the highest values obtained by plants from seeds with high vigor. In addition, the authors observed that the use of seeds with high vigor resulted in better stands in the field and plants with better development. Abati et al. (2018) observed in their study that high vigor wheat seeds obtained better establishment in the field, growth and performance of plants.

The number of spikes. $\mathrm{m}^{-2}$ was higher for Tbio Mestre and Tbio Iguaçú cultivars at Site 1. At cultivation Site 2, Tbio Mestre and Tbio Toruk cultivars reached a higher number of spikes. $\mathrm{m}^{-2}$ (Table 2). The number of spikes. $\mathrm{m}^{-2}$ was higher when high vigor seeds were used at both cultivation sites, but this number did not differ for medium vigor seeds at the cultivation Site 1 . The decrease in the plant population in the treatments with low vigor seeds (Table 2) can be related to the reduction of number of spikes per area.

In this sense, it is worth noting that there was an increase in the number of fertile tillers per plant when low vigor seeds were used (Table 4). Wheat is a crop with potential for producing tillers with fertile ears, which gives the species a certain plasticity that gives it the capacity to occupy empty spaces between plants (Mundstock, 1999). This result may be due to the plasticity of plants to occupy spaces because of the lack of plants in the sowing line. However, there was not enough compensation to match the number of spikes. $\mathrm{m}^{-2}$.

The number of spikelets in the main tiller at Site 1 for Tbio Toruk and Tbio Mestre cultivars was higher than for the Tbio Iguaçú cultivar, but it did not differ significantly between them. At Site 2, the cultivar Tbio Iguaçú reached the highest values for number of spikelets (Table 2).

When analyzing seed vigor levels, the number of spikelets in the main tiller was lower at the crop Site 1 using high vigor seeds. However, no significant differences were observed between the number of spikelets in the tillers when the crop Site 2 was analyzed.

For the number of seeds in the main tiller, no significant differences were observed between wheat cultivars grown at Site 1. However, when considering the cultivation Site 2, the cultivars Tbio Mestre and TBio Iguaçú reached higher values, without differing between them (Table 2). The expression of the productivity potential of the crops is dependent on the genetic attributes, environmental factors and the interaction between both, which culminates in differences in the performance of the genotypes (de Leon et al., 2016). Therefore, the expression of the performance of the different cultivars in this study, may be related not only to the characteristics inherent to each one of them, but also to their interaction with the cultivation environments.

In both cultivation sites, plants grown from medium and low vigor seeds showed a superiority in relation to the number of seeds in the main tiller, but they did not

Table 3: Unfolding of simple interaction effects between cultivars and vigor levels for plant height at Site 1 (Pelotas, Capão do Leão - RS) and number of plants.m ${ }^{-2}$ at Site 2 (Nova Boa Vista - RS), Capão do Leão, RS

\begin{tabular}{|c|c|c|c|c|c|c|}
\hline \multirow{2}{*}{$\begin{array}{l}\text { Vigor } \\
\text { Level }\end{array}$} & \multicolumn{3}{|c|}{ Plant height $(\mathrm{cm})$} & \multicolumn{3}{|c|}{ Number of plants. $m^{-2}$} \\
\hline & Toruk & Mestre & Iguaçú & Toruk & Mestre & Iguaçú \\
\hline High & $68.58 \mathrm{aC}^{*}$ & $78.20 \mathrm{abB}$ & $96.40 \mathrm{aA}$ & $330.88 \mathrm{aA}$ & $270.59 \mathrm{aB}$ & $282.35 \mathrm{aB}$ \\
\hline Medium & $72.96 \mathrm{aC}$ & $77.28 \mathrm{bB}$ & $92.60 \mathrm{aA}$ & $232.35 \mathrm{bA}$ & $264.70 \mathrm{abA}$ & $247.05 \mathrm{aA}$ \\
\hline Low & $71.45 \mathrm{aC}$ & $81.87 \mathrm{aB}$ & $87.14 \mathrm{bA}$ & $199.99 \mathrm{bA}$ & $229.41 \mathrm{bA}$ & $207.35 \mathrm{bA}$ \\
\hline CV (\%) & \multicolumn{3}{|c|}{3,65} & \multicolumn{3}{|c|}{9,84} \\
\hline
\end{tabular}

* Means followed by the same lowercase letter in columns and uppercase in lines do not differ by Duncan test ( $\mathrm{p} \leq 0.05$ ). 
differ statistically regarding low seed vigor (Table 2). According to Pimentel et al. (2018) certain compensatory strategies developed by the plants often cause certain yield components to be negatively related, thus increasing certain components and reducing others. In this sense, the results obtained can be explained by the plasticity capacity characteristic of wheat and the development of these compensation strategies.

The seed mass in the main tiller did not present significant differences between cultivars and seed vigor levels at both cultivation sites (Table 2). This result indicates that the highest number of seeds formed in spikes of the main wheat plant grown from medium and low vigor seeds is not sufficient to influence the production of seed mass, indicating a probable compensation during seed filling. In this sense, seed filling may have occurred more efficiently in plants grown from high vigor seeds. Bagateli (2015) in his study, found linear increases in the mass of a thousand soybean seeds, according to the increase in the seed vigor level.

By evaluating the number of fertile tillers at both sites, no significant differences were found between cultivars (Table 4). Plants grown from low vigor seeds reached a superiority in the number of fertile tillers for both crop sites. However, plants grown from high vigor seeds did not differ statistically from plants grown from low vigor seeds at the cultivation Site 2 .

The results for the number of fertile tillers may be related to the lower plant population established using low vigor seeds (Table 2). This indicates a plasticity effect of plants in an attempt to compensate for failures in sowing lines. As described by Santos \& Mundstock (2002), changes in the morphological structures of wheat stem occur from differences in management conditions, sowing density, and competitive and compensatory capacity (phenotypic plasticity) of cultivars.

The number of seeds produced in tillers did not differ between cultivars grown at both sites. The seed mass evaluated in tillers did not differ among the cultivars at Site 1. However, at Site 2, the Tbio Iguaçú cultivar reached higher values, but it did not differ from the cultivar Tbio Mestre (Table 4).

Regarding seed vigor level, the number of seeds produced in tillers was higher in plants grown from the low vigor seed lot at both sites. However, plants grown from seeds with a high vigor did not differ from plants grown from low vigor seeds at Site 2 as for the number of seeds in tillers (Table 4).

Similarly to the response of the number of seeds in tillers, plants grown from seed lots with a low vigor reached higher values of seed mass in tillers at both sites, whereas plants grown from high vigor seeds obtained the worst results at Site 1, without differing from plants grown from low vigor seeds at the Site 2 . This can be related to the number of plants per square meter, which was significantly lower for the low vigor seed lot.

It is noticeable that plants grown from seeds with a low vigor seek to occupy spaces in sowing lines without plants, emitting more tillers due to less competition among plants. Consequently, the production of seeds in tillers is higher. The effects of competition between plants are decisive for the production of tillers, with direct implications on the productivity of grains and their components (Semeato, 2016). In this sense, the number of

Table 4: Number of fertile tillers (Nft), number of seeds in tillers (Nst), seed mass (g) in tillers (Smt), and grain yield.ha ${ }^{-1}$ (Prod) of wheat plants grown from seeds with three vigor levels, Capão do Leão, RS

\begin{tabular}{|c|c|c|c|c|c|c|c|c|}
\hline & Site 1 & Site 2 & Site 1 & Site 2 & Site 1 & Site 2 & Site 1 & Site 2 \\
\hline & \multicolumn{2}{|c|}{ Nft } & \multicolumn{2}{|c|}{ Nst } & \multicolumn{2}{|c|}{ Smt (g) } & \multicolumn{2}{|c|}{ Prod. (kg.ha-1) } \\
\hline \multicolumn{9}{|l|}{ Cultivar } \\
\hline Toruk & $1.64 a^{*}$ & $1.48 \mathrm{a}$ & $44.15 \mathrm{a}$ & $39.17 \mathrm{a}$ & $1.73 \mathrm{a}$ & $0.636 b$ & $5991.02 \mathrm{a}$ & $4218.31 \mathrm{a}$ \\
\hline Mestre & $1.69 \mathrm{a}$ & $1.63 \mathrm{a}$ & $51.36 \mathrm{a}$ & $42.63 a$ & $1.72 \mathrm{a}$ & $0.741 \mathrm{ab}$ & $5548.93 b$ & $4423.57 \mathrm{a}$ \\
\hline Iguaçú & $1.78 \mathrm{a}$ & $1.71 \mathrm{a}$ & $46.33 \mathrm{a}$ & $46.09 \mathrm{a}$ & $1.63 \mathrm{a}$ & $0.815 \mathrm{a}$ & $5321.49 \mathrm{~b}$ & $4541.80 \mathrm{a}$ \\
\hline \multicolumn{9}{|l|}{ Vigor Level } \\
\hline High & $1.52 \mathrm{~b}$ & $1.60 \mathrm{ab}$ & $38.68 \mathrm{~b}$ & $42.25 \mathrm{ab}$ & $1.29 \mathrm{c}$ & $0.701 \mathrm{~b}$ & $5842.27 \mathrm{a}$ & $4744.58 \mathrm{a}$ \\
\hline Medium & $1.66 \mathrm{~b}$ & $1.46 \mathrm{~b}$ & $45.36 \mathrm{~b}$ & $38.35 b$ & $1.69 \mathrm{~b}$ & $0.658 \mathrm{~b}$ & $5858.51 \mathrm{a}$ & $4174.58 b$ \\
\hline Low & $1.94 \mathrm{a}$ & $1.76 \mathrm{a}$ & $57.81 \mathrm{a}$ & $47.3 \mathrm{a}$ & $2.09 \mathrm{a}$ & $0.833 \mathrm{a}$ & $5160.66 \mathrm{~b}$ & $4264.52 b$ \\
\hline \multicolumn{9}{|l|}{ Value of F } \\
\hline Cultivar (C) & $1.11^{\mathrm{ns}}$ & $2.32^{\mathrm{ns}}$ & $1.89^{\text {ns }}$ & $1.93^{\mathrm{ns}}$ & $0.306^{\mathrm{ns}}$ & 4.29 & $6.13 *$ & $2.02^{\mathrm{n}}$ \\
\hline Vigor(V) & $9.29 *$ & $3.70 *$ & $12.99 *$ & $3.24 *$ & $15.714^{*}$ & $4.43^{*}$ & $8.39 *$ & $7.09 *$ \\
\hline $\mathrm{CxV}$ & $1.06^{\mathrm{ns}}$ & $0.610^{\mathrm{ns}}$ & $0.461^{\mathrm{ns}}$ & $0.49^{\text {ns }}$ & $0.803^{\mathrm{ns}}$ & $0.609^{\text {ns }}$ & $2.06^{\mathrm{ns}}$ & $1.4^{\mathrm{ns}}$ \\
\hline $\mathrm{CV}(\%)$ & 14.12 & 16.67 & 19.73 & 20.27 & 20.98 & 20.49 & 8.48 & 9.07 \\
\hline
\end{tabular}

* Means followed by the same lowercase letter in rows do not differ by Duncan test ( $\leq \leq .05)$.

Site 1: Pelotas; Capão do Leão; Site 2: Nova Boa Vista.

Rev. Ceres, Viçosa, v. 69, n.1, p. 113-120, jan/feb, 2022 
plants in a given area has an influence and can be decisive for the balance of yield components and, consequently, productivity. In the wheat crop, the number of plants per unit area influences the architecture of the plants and the emission of tillers (Benin et al., 2012), which justifies the superior results obtained by plants from seeds with low vigor, which showed lower number of plants $\mathrm{m}^{2}$.

The cultivar Tbio Toruk reached high values of grain yield at Site 1. However, no significant differences were observed in grain yield among cultivars at Site 2 (Table 4).

Productivity is significantly affected by seed vigor levels. The highest values are reached when high vigor seeds are used. There was a productivity difference of approximately $10-11 \%$, corresponding to a productivity of 480 and $669 \mathrm{~kg} \cdot \mathrm{ha}^{-1}$ in relation to high and low vigor seeds at Sites 2 and 1, respectively.

In relation to increased productivity, factors such as obtaining a uniform stand, higher percentage of seedling emergence, higher initial seedling growth, increased leaf area, and dry mass may explain a better use of resources by plants with a high vigor, which allows the achievement of a greater productive potential (Mielezrski et al., 2008; Scheeren et al., 2010; Schuch et al., 1999; Schuch et al. 2000). In addition, it is noteworthy that for certain species, low vigor can culminate in the formation of insufficient plant populations by area, negatively altering the final production (Marcos Filho \& Novembre, 2009). In this sense, there is research for crops such as rice and soy, which prove that the use of seeds with low vigor results in changes in the initial stand and consequently imply significant reductions in plant productivity (França-Neto, 2012; Mielezrski et al., 2008).

Therefore, in several species, the vigor of the seeds influences the productivity of the crops. In studies on rice crops (Oryza sativa L.), Melo et al. (2006) found that plant communities grown from high vigor seeds reach yields higher than $20 \%$ in relation to plant communities grown from low vigor seeds. For soybean (Glycine max L. Merril), Bagateli et al. (2020) observed that the use of high vigor seeds resulted in increases in productivity of up to $19 \%$ compared to the use of low vigor seeds. Other authors have found significant increases in the productivity of soybeans for the cultivation of plants grown from highly vigorous seeds: 25,2\% (Rodrigues et al., 2018), 20\% (Tavares et al., 2013). In addition, Silva et al. (2016) found that the increase in vigor provided an increase in the productivity of corn hybrids.

The use of high vigor seeds provides the best establishment of plant stands, resulting in a greater number of spikes per area and a higher seed productivity (up to $11 \%$ ). On the other hand, there is a plasticity effect of low vigor plants due to the lack of plants in sowing lines. There is an increase in the number of fertile tillers and in the number of seeds in tillers. However, this effect is not sufficient to compensate for the lower population of plants, adversely affecting the productivity of wheat seeds.

\section{CONCLUSIONS}

The cultivars present different performances when cultivated from seeds with different levels of vigor.

The use of low vigor seeds negatively affects the establishment of wheat plant stands.

The use of high vigor seeds provides a greater number of wheat plants and spikes per area.

Grain yield is affected significantly by seed vigor level. There is an increase of up to $11 \%$ using high vigor seeds compared to low vigor seeds.

\section{ACKNOWLEDGEMENTS, FINACIAL SUPPORT, AND FULL DISCLOSURE}

This work was carried out with the support of CNPq, National Council for Scientific and Technological Development, Brazil. Thanks to CNPq for the research productivity grant - PQ2 granted to the last author.

The authors declare than there in not conflict of interest.

\section{REFERENCES}

Abati J, BrzezinskI CR, Foloni JSS, Zucareli C, Bassoi MC \& Henning FA (2017) Seedling emergence and yield performance of wheat cultivars depending on seed vigor and sowing density. Journal of Seed Science 39:58-65.

Abati J, Brzezinski CR, Zucareli C, Foloni JSS \& Henning FA (2018) Crescimento e rendimento de trigo em resposta ao vigor de sementes e densidade de semeadura. Revista Caatinga, 31:891-899.

Bagateli JR (2015) Desempenho produtivo da soja originada de lotes de sementes com diferentes níveis de vigor. Dissertação de Mestrado. Universidade Federal de Pelotas, Pelotas. 34p.

Bagateli JR, Franco JJ, Meneghello GE \& Villela FA (2020) Vigor de sementes e densidade populacional: reflexos na morfologia de plantas e produtividade da soja. Brazilian Journal of Development, 6:38686-38718.

Benin G, Pinnow C, Silva CL, Pagliosa ES, Beche E, Bornhofen E, Munaro LB \& Silva RR (2012) Análises biplot na avaliação de cultivares de trigo em diferentes níveis de manejo. Bragantia, 71:28-36

Brasil (2009) Ministério da Agricultura, Pecuária e Abastecimento. Regras para análise de sementes. Secretaria de Defesa Agropecuária. Brasília, MAPA. 399p.

Carneiro THM, Cavalcante AG, Cavalcante ACP, Andrade GAV, Lima NJC \& Aquino LA (2020) Efeito do vigor de sementes sobre as características fisiológicas e produtivas da soja. Acta Iguazu, 9:122-133.

CQFS RS/SC - Comissão de Química e Fertilidade do Solo (2004) Manual de adubação e calagem para os estados do Rio Grande do Sul e Santa Catarina. 10th ed. Porto Alegre, Sociedade Brasileira de Ciência do Solo/Núcleo Regional Sul. 400p. 
CONAB - Companhia Nacional de Abastecimento (2017) A cultura do trigo. Available at: <https://www.conab.gov.br/uploads/arquivos/17_04_25_11_40_00_a_cultura_do_trigo_versao_digital_final.pdf >. Accessed on: May 15th, 2020.

CONAB - Companhia Nacional de Abastecimento (2019) Acompanhamento de safra brasileira de grãos, safra 2019/20. Available at: https://www.conab.gov.br/info-agro/safras/graos/boletim-dasafra-de-graos. Accessed on: May 12th, 2020.

Ebone LA, Carvezan A, Tagliari A, Chiomento JLT, Silveira DC \& Chavarria G (2020) Soybean seed vigor: uniformity and growth as key factors to improve yield. Agronomy 10:01-15.

Egli DB \& Rucker M (2012) Seed vigor and the uniformity of emergence of corn seedlings. Crop Science, 52:2774-2782.

Embrapa - Empresa Brasileira de Pesquisa Agropecuária (2017) Informações técnicas para trigo e triticale - safra 2017. Londrina, Embrapa. 240p.

França-Neto JB (2012) Plantas de alto desempenho e a produtividade de soja. Seed News, 16:08-11.

França-Neto JB, Krzyzanowski FC, Henning AA, Pádua GP, Lorini I \& Henning FA (2016) Tecnologia da produção de semente de soja de alta qualidade. Londrina, Embrapa Soja. 82p.

Kolchinski EM, Schuch LOB \& Peske ST (2005) Vigor de sementes e competição intraespecífica em soja. Ciência Rural, $35: 1248-1256$.

Leon N, Jannink JL, Edwards JW \& Kaeppler SM (2016) Introduction to a Special Issue on Genotype by Environment Interaction. Crop Science 56:2081-2089.

Marcos Filho J \& Novembre ADLC (2009) Avaliação do potencial fisiológico de sementes de hortaliças. In: Nascimento WM (Ed.) Tecnologia de sementes de hortaliças. Brasília, Embrapa Hortaliças. p.185-246.

Marcos Filho J (2015) Fisiologia de sementes de plantas cultivadas. Londrina, Abrates. 659p.

Melo PTBS, Schuch LOB, Assis FN \& Concenço G (2006) Comportamento individual de plantas originadas de sementes com diferentes níveis de qualidade fisiológica em populações de arroz irrigado. Revista Brasileira de Sementes, 28:84-94.

Mielezrski F, Schuch LOB, Peske ST, Panozzo LE, Peske FT \& Carvalho RR (2008) Desempenho individual e de populações de plantas de arroz híbrido em função da qualidade fisiológica das sementes. Revista Brasileira de Sementes, 30:86-94.

Mundstock CM (1999) Planejamento e manejo integrado da lavoura de trigo. Porto Alegre, UFGRS. 228p.

Pedroso DC, Tunes LM, Barbieri AP, Barros ACSA, Muniz MFB \& Menezes VO (2010) Envelhecimento acelerado em sementes de trigo. Ciência Rural, 40:2389-2392.

Peske ST, Villela FA \& Meneguello GE (2019) Sementes: Fundamentos Científicos e Tecnológicos. 4a ed, Pelotas, UFPel. 415p.
Pimentel JR, Troyjack C, Dubal ITP, Koch F, Monteiro MA, Escalera RAV, Szareski VJ, Carvalho IR, Nascimento HWFDO, Martinazzo EG, Pedroso CES, Schuch LOB, Pedó T \& Aumonde TZ (2018) Desenvolvimento inicial e componentes do rendimento em resposta à associação entre nível de vigor e profundidade de semeadura na cultura do trigo. Revista Brasileira de Tecnologia Agropecuária, 2:18-24.

Rodrigues DS, Schuch LOB, Meneghello GE \& Peske ST (2018) Desempenho de plantas de soja em função do vigor das sementes e do estresse hídrico. Revista Científica Rural, 20:144-158.

Rossi RF, Cavariani C \& França-Neto JB (2017) Vigor de sementes, população de plantas e desempenho agronômico de soja. Revista de Ciências Agrárias, 60:215-222.

Santos HP \& Musndtock CM (2002) Parâmetros da habilidade competitiva no estabelecimento de populações caracterizam o potencial de produção individual em trigo e aveia. Revista Brasileira de Botânica, 25:43 53.

Scheeren BR, Peske ST, Schuch LOB \& Barros ACA (2010) Qualidade fisiológica e produtividade de sementes de soja. Revista Brasileira de Sementes, 32:35-041.

Scheeren PL, Caierão E, Silva MS \& Bonow S (2011) Melhoramento de trigo no Brasil. In: Pires JLF, Vargas L \& Cunha GR (Eds.) Trigo no Brasil: bases para produção competitiva e sustentável. Passo Fundo, Embrapa. p. 427-452.

Schuch LOB, Nedel JL, Assis FN \& Maia MS (1999) Crescimento em laboratório de plântulas de aveia preta (Avena strigosa Schreb.) em função do vigor das sementes. Revista Brasileira de Sementes, 21:229-234.

Schuch LOB, Nedel JL, Assis FN \& Maia MS (2000) Emergência a campo e crescimento inicial de aveia preta em resposta ao vigor de sementes. Revista Brasileira de Agrociência, 6:97-101.

Semeato EC (2016) Estratégias para boa densidade de semeadura. Cultivar Máquinas, 162:12-15.

Silva DHR, Meneghello GE, Oliveira S, Cavalcante JA \& Tunes LM (2016) População de plantas e desempenho produtivo de híbridos de milho oriundos de sementes com diferentes níveis de vigor. Revista Verde de Agroecologia e Desenvolvimento Sustentável, 11:01-04.

Takeiti CY (2015) Árvore do conhecimento - trigo. Agência Embrapa de Informação Tecnológica. Available at: <https://www.agencia.cnptia.embrapa.br/gestor/tecnologia_de_alimentos/arvore/ CONT000girlwnqt02 wx 5 ok05vadr 1 qrnof $0 \mathrm{~m} . \mathrm{html}$ : : : te$\mathrm{xt}=\mathrm{Ag} \% \mathrm{C} 3 \%$ AAncia\%20Embrapa $\% 20 \mathrm{de} \% 20$ Informa\%C3\%A$7 \% \mathrm{C} 3 \%$ A3o\%20 Tecno1\%C3\% B3gica,e $\% 20 \mathrm{Kwait}) \% 20$ do$\% 20 \mathrm{M} \% \mathrm{C} 3 \%$ A9dio\%20Oriente>. Accessed on: May 5th, 2020.

Tavares LC, Rufino CA, Brunes AP, Tunes LM, Barros ACSA \& Peske ST (2013) Rendimento e qualidade de sementes de soja de alto e baixo vigor submetidas ao déficit hídrico. Interciencia, 31:73-80.

USDA (1999) Soil taxonomy: A basic system of soil classification for making and interpreting soil surveys. Washington, USDA. $866 \mathrm{p}$. 